\title{
REFLEKSI TERHADAP PEMBANGUNAN DAN ANCAMAN GLOBALISASI
}

\author{
Ahmad Syukri \\ INSTITUT AGAMA ISLAM NEBERI METRO
}

Sunny1922@yahoo.co.id

\begin{abstract}
Development as a paradigm and the theory of social change today is in crisis and fails to apply in various Third World countries. The failure of development in the third world actually occurs in the countries that are considered the most successful and most widely used as examples for other development countries. Namely capitalist countries model of NIC (newly industrialist countries) such as South Korea and Taiwan. Development failures also occur in countries that are modeled as new NIC countries such as Thailand, Malaysia, and Indonesia. Until now the explanation of various crises has not been completed. There is an explanation that blames the regime's corruption factor as an argument for explaining the rapid fall of capitalism in Asia. Nevertheless, a discourse before the fall of Asian capitalism occurred has begun in the wake of an attempt to repair or reform the system of capitalism. As a process of reform, the approach, ideology, and structure of discourse are not much different from the systems, structures and ideologies that are the foundation of development theory. Discourse that is known globalization.
\end{abstract}

Key word: reflection, development, human resources 


\section{A. PENDAHULUAN}

Pembangunan sebagai suatu paradigma dan teori perubahan sosial dewasa ini berada pada masa krisis dan mengalami kegagalan penerapan diberbagai Negara dunia ketiga. Kegagalan pembangunan di dunia ketiga justru terjadi pada Negara-negara yang dianggap paling sukses dan paling banyak dijadikan contoh bagi Negara-negara penganut pembangunan lainnya. Yakni Negara-negara kapitalis model NIC (new industrialist countries) seperti korea selatan dan Taiwan. Kegagalan pembangunan juga terjadi di Negara yang dijadikan model yakni Negara-negara NIC baru seperti Thailand, Malaysia dan Indonesia.

Sampai saat ini penjelasan berbagai krisis belum selesai. Ada penjelasan yang menyalahkan factor korupsi rezim Negara-negara tersebut sebagai argument untuk menjelaskan kejatuhan kapitalisme di Asia yang terjadi secara cepat. Meskipun demikian, suatu diskursus sebelum kejatuhan kapitalisme Asia terjadi telah mulai di bangun dengan percobaan untuk memperbaiki atau mereformasi system kapitalisme. Sebagai suatu proses reformasi maka pendekatan, ideology, dan struktur diskursus itu tidak jauh beda dengan system, struktur dan ideologi yang dijadikan landasan teori pembangunan. Diskursus itulah yang dikenal globalisasi. ${ }^{1}$

Proses globalisasi ditandai dengan pesatnya perekembangan paham kapitalisme, yakni kian terbuka dengan menglobalnya peran pasar, investasi dan proses produksi dari perusahaan-perusahaan transnsional, yang kemudian dikuatkan dengan ideology dan tata perdagangan bebas secara global. Namun globalisasi muncul bersamaan dan menjadi bagian fenomena runtuhnya pembangunan di Asia Timur.

Era baru yang dikenal globalisasi tersebut mencoba meyakinkan rakyat miskin didunia ketiga seolah-olah merupakan arah baru yang menjanjikan harapan perbaikan umat manusia dan menjadi keharusan sejarah manusia dimasa depan. Namun globalisasi juga melahirkan kecemasan bagi mereka yang memikirkan permasalahan pemiskinan rakyat yang marjinal serta persoalan keadilan sosial. Bersamaan dengan itu, fenomena yang juga berkembang pesat dan berakibat semakin meningkatnya kemajuan bidang komunikasi, elektronika serta bioteknologi yang dikuasai perusahaan transnasional. Sementara itu, dipihak lain dunia juga masih menghadapi krisis hutang dan krisis over produksi warisan pembangunan tahun 80-an serta warisan dampak negative dari kampanye internasional yang dulu dikumandangkan oleh The Bretton Woods Institutions tentang model pembangunan ekonomi pertumbuhan.

${ }^{1}$ Dr. Nasikun, system sosial Indonesia, UGM-Yogyakarta, 2002. H. 35 


\section{B. REFLEKSI MENUJU ERA PACA PEMBANGUNAN}

Teori pembangunan atau dikenal dengan paham Developmentalisme, selain dikembangkan dalam rangka pengaruh dan semangat antikapitalisme bagi berjuta-juta didunia ketiga, juga siasat baru untuk menggantikan formasi sosial kolonialisme yang baru runtuh. Diskursus developmentalisme muncul tahun 1949, yakni saat presiden Harry S. Truman mengumumkan kebijakan pemerintahnya, dan sejak itu telah resmi menjadi bahasa dan doktrin kebijakan luar negri Amerika Serikat.

Bagaimana teori sosial pada tahun 1950-an dan 60-an, memainkan peranan penting dalam pembangunan diskursus akademik yang member legimitasi ilmiah terhadap teori tersebut sudah dianalisis. Analisis ditujukan pada suatau kejadian tahun1968 ketika berbagai pakar dari berbagai disiplin ilu sosial telah terlibat secara mendalam sampai mempengaruhi kebijakan Amerika tentang developmentalisme. Para ahli ilmu sosial tersebut berhasil membuat saran kepada pemerintah Amerika waktu itu yang intinya adalah bagaimana melakukan penaklukan ideology dan teoritis terhadap duniia ketiga. Tugas utama mereka adalah melakukan study tentang bagaimana kebijakan pemerintah Amerika dalam era perang dingin tersebut. Sejak saat itu ilmuwan sosial terdorong untuk menjadi sangat produktif sehingga berhasil menciptakan pengetahuan dan teori development dan modernisasi.

Teori pembangunan memang bermacam-macam, tetapi umumnya mereka meyakini satu hal yang sama yakni bahwa factor manusia (bukan struktur dan system) menjadi focus utama mereka. Pertama, yang menggunakan metafora pertumbuhan yakni tumbuh sebagai organism. Mereka melihat development sebagai proses evolusi perjalana dari tradisional ke modern. ${ }^{2}$ Pikiran ini dapat kita jumpai dalam teori pertumbuhan yang dikembangkan WW. Rostow (1960). Asumsinya adalah bahwa masyarakat, termasuk masyarakat Barat, pernah mengalami tradisional dan akhirnya menjadi modern. Sikap manusia tradisional dianggap sebagai masalah. Seperti pandangan Rostow dan pengikutnya, development akan berjalan secara hamper otomatis melalui akumulasi (tabungan dan investasi) dengan tekanan dan bantuan hutang luar negri. Dia memfokuskan pada perlunya elit wiraswata yang menjadi motor proses itu. Hal ini berdasarkan tafsir ata Max Weber, jika etika protestan menjadi pendorong pertumbuhan di Barat, analog yang sama juga bisa untuk melihat pertumbuhan ekonomi. ${ }^{3}$ Apa rahasia pikiran weber tentang etika protestan menurutnya adalah the need for achievement ( $\mathrm{N}^{\prime}$ Ach). Alas

\section{INTAN}

2 Prof. Dr. bambang sumitro, kuliah sosiologi pembangunan, PPs IAIN RADEN

3 A. Zaeni, S.Ag. Teri Weber dan islam, sosiologi agama, PPs IAIN RADEN INTAN 
an mengapa rakyat dunia ketiga terbelakang menurutnya karena rentannya $\mathrm{N}^{\prime}$ Ach. Sekali lagi sikap dan budaya dianggap sebagai masalah. ${ }^{4}$

Konsep pembangunan dan modernisasi kemudian serta merta dianut berjuta-juta rakyat dunia ketiga tersebut pada dasarnya refleksi dari paradigma Barat tentang perubahan sosial. Yang dimaksud modern disini merefleksikan pada bentuk perkembangan dan kemajuan teknologi dan ekonomi yang dialami oleh Negara-negara industry. Konsep ini mempunyai akar sejarah dan intelektual perubahan sosial yang diasosiasikan dengan revolusi industry dan Eropa.

Gagasan developmentalisme segera menjadi program massif, justru setelah menjadi doktrin politik bantuan luar Negeri Amerika baik pada pemerintah dunia ketiga maupun LSM, juga serempak hamoir di setiap Universitas di Barat membuka suatu kajian baru yang dikenal dengan Development studies. Melalui development studies ini, proses penyebar luasan gagasan kapitalisme dipenjuru dunia dipercepat, yakni melalui tehnokrat, intelektual, dan bahkan aktivis LSM dari dunia ketiga yang menjadi pasar utama program studi tersebut.

Para ahli ilmu sosial memainkan peran yang besar dalam menglobalisasikan ideology baru ini, dengan mengajukan gagasan kepada pemerintah Amerika untuk menggunakan berbagai cara dalam rangka mendeseminasikan ideology development dan modernisasi tersebut dengan target khusus dunia ketiga. Pertama, sasaran mereka, untuk menggunakan pengaruh Amerika, kebijakan ekonomi dan perencanaan. Mereka tahu bahwa bantuan Amerika selama ini efektif dalam mempengaruhi kebijakan ekonomi dan perencanaan. Kedua, untuk mendidik pemimpin dunia ketiga baik dalam bentuk training, maupun perjalanan observasi ke Amerika. Saran ketiga, dengan menggunakan saran agama. Banyak studi agama diarahkan pada peran agama dalam development, sehingga perlunya, "sekularisasi" menjadi bahasa resmi pemimpin dunia ketiga. Sedangkan yang terakhir adalah untuk menggunakan fungsi training dan riset dari tenaga Universitas Amerika yang bekerja diluar negeri atas biaya USAID. ${ }^{5}$

Doninasi dan invansi cultural, politik dan ekonomi dari developmentalisme selain didukung pemerintah dunia utara juga di dukung lembaga-lembaga dana internasional seperti Bank Dunia dan IMF. Dimana lembaga-lembaga tersebut dikembangkan dalam rangka menjaga status quo, dan untuk mengikat Negara-negara selatan pada ekonomi

${ }^{4}$ A. Fauzie Nurdin, Transformasi sosial keagamaan dalam perspektif sosiologi, makalah dalam seminar internasional, 2001.

${ }^{5}$ Millikan and Pye, 1968, p; 165 dikutip oleh Dr. Mansour Fakih, Runtuhnya teori pembangunan, pustaka pelajar, Yogyakarta, h.203 
Negara kaya. Bahkan sebagian besar dari apa yang disebut bantuan biasanya digunakan pemerintah dunia ketiga untuk melayani kepentingan Bank Dunia. Sebagian yang lain dijatahkan oleh pemberian bantuan dalam rangka melincinkan eksportir serta mendukung bisnis mereka sendiri yang mereka tanam di dunia ketiga. ${ }^{6}$

Demikianlah discourse development terus berkembang, dimasingmasing Negara berkembang secara mendalam sehingga sampai dipedesaan dengan pendekatan masing-masing. Di Indonesia, misalnya, ideology developmentalisme yang kemudian diterjemahkan dalam pembangunan tersebut dikembangkan melalui mekanisme dikontrol, ideology, sosial dan politik yang canggih. Untuk melindungi ideology pembangunan tersebut aparat pembangunan menegakkan berbagai pendekatan seperti the floating mass polisy, yakni suatu kebijakan yang melarang semua organisasi massa pada tingkat desa. Kebijakan lain berupa penggeseran system pemilihan lurah yang dilakukan secara demokratis dan menggantikan nya dengan menempatkan militer sebagai kepala desa, bahkan memperkokoh organisasi militer untuk setiap desa (Babinsa). Secara politik ditetapkannya undang-undang peraturan pemerintah desa sejak tahun 1979 untuk menggantikan tradisi rembuk desa dengan lembaga desa yang dikontrol pemerintah. Secara ekonomi diciptakan KUD sebagai satu-satunya koperasi yang diizinkan beroperasi di tingkat kecamatan. Gagasan pembangunan juga dikembangkan melalui pendidikan, baik formal maupun non-formal (kursus, seminar bahkan khotbah di masjid-masjid dan pengajian). Program pembangunan diselenggarakan melalui organisasi besar dalam departemen pemerintah dengan skala besar dan nasional, sampai pedesaan yang didukung oleh banyak lembaga swadaya masyarakat telah diterima tanpa pertanyaan. Umumnya perdebatan hanya dilakukan pada tingkat cara, metodologi dan tehnik pelaksanaannya belaka, dan bukan pada level prinsipnya. Bisa disimpulkan bahwa developmentalisme dewasa ini diyakini oleh sebagian besar biokrat pemerintah akademisi dan bahkan banyak aktivis sosial menjadi satu-satunya perubahan sosial menuju masyarakat modern sejahtera.

Namun demikian, menjadi kekecewaan meluas dikalangan teoritis ilmuwan sosial terutama yang menekuni teori perubahan sosial dan teori pembangunan terhadap developmentalisme. Developmentalisme tidak hanya gagal menjawab berbagai persoalan yang wariskan pemikir sebelumnya, seperti persoalan kelas, dominasi ideology, dan budaya, persoalan gender dan lingkunagn, bahkan justru dianggap melanggengkannya. Misalnya, tentang bagaimana memecahkan persoalan eksplotasi buruh yang melekat pada system kapitalis. Para konseptor 
developmentalisme sudah tidak membahas nya lagi. Keadaan tersebut membawa pada sikap para penganutnya yang tidak pernah mampu memecahkan krisis perburuhan secara mendasar.

Developmentalisme juga diakui telah gagal untuk menghindari system penindasan politik masyarakat. Watak dasar positivisme ${ }^{7}$ yang menjadi pilar dalam developmentalisme tidak melihat bahwa rekayasa sosial sebagai problematika, akibatnya paham tersebut tidak sensitive terhadap masyarakat, terutama masyarakat adat. Developmentalisme sejak diciptakan juga menjadi bagian dari masalah lingkungan hidup. Jalan keluar yang ditawarkan, yakni pembangunan yang berkelanjutan, tidak memuaskan karena bertentangan dengan ide pertumbuhan dan keuntungan yang melekat pada ideologinya. Akibatnya developmentalisme menjadi bagian dari masalah lingkungan hidup dari pada sebagian jalan keluar. Pendek kata, selama setengah abad, pembangunan berhasil menjadi ideology yang mapan, paradigm mainstream, diskursus yang dominant, dan menjadi homogeni dominant kelompok elit ditingkat akar rumput.

Sungguhpun demikian, sampai menjelang millennium kita menyaksikan dominasi diskursus dan paradigma pembangunan itu runtuh bersamaan dengan krisis kapitalisme di Asia Timur. Namun, permasalahannya, ternyata hingga saat ini belum ada teori alternative terhadap developmentalisme. Berbagai argumentasi dan penjelasan enggan dibangun untuk melindungi developmentalisme, bahwa krisis yang terjadi di Asia adalah kesalahan ideologis. Mereka tengah melakukan pembelaan dengan menyatakan bahwa krisis ini karena korupsi, kolusi dan nepotisme para penguasa dunia ketiga. Padahal, kegagalan dan krisis yang menimpa dunia ketiga karena mereka tidak taat azas terhadap pendirian liberalism, dan solusi yang ditawarkan adalah perlunya pelaksanaan agenda liberalisme seperti kebijakan yang anti proteksi pada rakyat; jauhkan campur tanagn pemerintah dalam perdagangan, tingkatkan perlindungan bagi investasi dan proses produksi; hilangkan subsidi rakyat; namun tegakkan hukum yang melindungi industry; serta kembangkan pemerintah yang bersih (good governance) dan transparan. Tidak ada satu uraian resmi yang mengarah bahwa krisis yang terjadi adalah kegagalan modernisasi, pembangunan dan kegagalan karena dianutnya ideology kapitalisme.

\section{DARI PEMBANGUNAN KE GLOBALISASI}

Krisis pembangunan dewasa ini terjadi pada dasarnya merupakan bagian dari krisis sejarah dominasi dan eksploitasi manusia atas manusia yang lainnya, yang diperkirakan telah berusia lebih dari 500 tahun. Proses sejarah dominasi itu pada dasar nya dapat dibagi kedalam tiga periode formasi sosial. Fase pertama, adalah periode kolonialisasi yakni fase

${ }^{7}$ A. Zaini, Teori-teori pembangunan, makalah, 2003 
perkembangan kapitalisme Eropa yang mengharuskan ekspansi secara fisik untuk memastikan perolehan bahan baku mentah. Fase kedua neo kolonialisme, ketika modus dominasi penjajahan tidak lagi fisik dan secara langsung, melainkan melalui penjajahan teori dan ideology. Fase kedua ini dikenal sebagai era pembangunan atau era developmentalisme. Periode ini dimulai dengan masa kemerdekaan Negara dunia ketiga secara fisik, tetapi pada era developmentalisme dominasi bekas Negara-negara jajahan terhadap bekas koloni mereka tetap dipertahankan melalui control terhadap teori dan proses perubahan sosial. ${ }^{8}$

Krisis terhadap pembangunan belum berakhir, tetapi suatu mode domination_telah disiapkan dan dunia memasuki era baru yakni era globalisasi. Periode ketiga, yang dikenal dengan menjelang abad ke 21, ditandai dengan liberalisasi disemua bidang yang dipaksakan melalui structurel adjustment program oleh lembaga financial global, yang disepakati oleh rezim perdagangan bebas (WTO;World Trade Organization). Sejak saat itu era baru telah muncul menggantikan era sebelumnya, dan dengan begitu dunia memasuki periode yang dikenal globalisasi. Secara lebih tegas yang dimaksud globalisasi adalah proses pengintegrasian ekonomi nasional kepada system ekonomi dunia berdasarkan keyakinan pada perdagangan bebas yang sesungguhnya telah dicanangkan sejak kolonialisme.

Secara teoritis sebenarnya tidak ada perubahan ideology dari ketiga periode zaman tersebut, bahkan semakin bertambah canggih pendekatan, mekanisme dan system yang secara ekonomis berwatak eksploitatif, secara politik berwatak refresif dan secara budaya berwatak hegemaonik dari sebagian kecil elit masyarakat yang mendominasi terhadap rakyat kecil. Dalam kerangka periodisasi sejarah seperti itu peranan teori dan paradigma perubahan sosial dapat dipahami. Jika pada era kolonialisme ilmu sosial melegitimasi dengan mengembangkan teori evolusi dan Darwinisme, pada era selanjutnya teori dan ideology ilmu-ilmu sosial modernisasi dan neo liberalisasi juga berperan melegimitasi development dan globalisasi. Perbedaan yang terpenting era pembangunan dan globalisasi diantaranya, jika pembangunan lebih menekankan pada pertumbuhan ekonomi nasional dan mereka lebih melihat kedalam negeri sendiri, dalam era globalisasi mereka didorong untuk menjadi bagian dari pertumbuhan ekonomi global, dimana actor-aktornya bukan hanya Negara tapi perusahaan transnasional (TNCs) dan Bank-Bank transnasional (TNBs), serta lembaga keuangan multilateral seperti Bank Dunia dan IMF, serta biokrasi perdagangan regional dan global seperti WTO, Nafta, Apec, ASEAN dan sebagainya.

8 Dr.Mansour Fakih, Runtuhnya teori pembangunan, pustaka pelajar, Yogyakarta, 2001, h. 2009 


\section{TANTANGAN TERHADAP GLOBALISASI}

Sejak dicanangkan penandatanganan kesepakatan GATT, NAFTA, APEC, serta didirikannnya WTO dan dilaksanakanya structural adjustment program oleh Bank Dunia merupakan pertanda globalisasi tengah berlangsung. Bahkan dengan tumbuhnya kwasan-kawasan segitiga pertumbuhan regional antara Negara maupun kawasan pertumbuhan terpadu suatu kawasan industry yang bebas dari campur tangan pemerintah maupun kawasan pertumbuhan terpadu diberbagai wilayah, maka sesungguhnya globalisasi telah mulai. Sungguhpun demikian persamaan dengan pesatnya dan kemajuan globalisasi dari tingkat internasional hingga tingkat local. Berbagai korban terutama masyarakat adapt, kaum miskin kota dan golongan marjinal lainnya telah mulai dirasakan. Meskipun hampir semua pemerintah menerima globalisasi dan mulai melakukan penyesuaian kebijakan dan undang-undang dalam negeri sesuai dengan kebijakan yang disepakati dalam aturan global menyangkut soal investasi, hambatan perdagangan, pertanian dan pertanahan, pajak dan hak paten dan lain sebagainya, namun sesungguhnya masing-masing rakyat Negara tersebut belum tentu sepenuhnya menerima globalisasi 9 . Akibatnya pada saat ini mulai tumbuh gerakan tantangan maupun resistensi terhadap globalisasi baik ditingkat internasional maupun tingkat local. Arena-arena resistensi dan tantangan terhadap globalisasi tersebut dapat diidentifikasikan sebagai berikut ;

Pertama, tantangan gerakan cultural dan agama terhadap globalisasi. Sudah lama terdapat fenomena lahirnya gerakan yang berbasis agama maupun gerakan resistensi budaya melawan pembangunan dan globalisasi. Gerakan berbasis agama ini timbul dimana-mana dan dengan lebel yang bermacam-macam. Di Mesir kekecewaan terhadap pembangunan yang melanda kalangan warga muslim miskin perkotaan tersebut telah melahirkan gerakan yang berbasis keagamaan yang dilabeli dengan Fudndamentalisme Islam. Gerakan resistensi keagamaan terhadap pembangunan dan globalisasi ditempat lain juga melahirkan suatu gerakan teologi yang bercorak pembebasan dalam islam seperti yang terjadi di Indonesia. ${ }^{10}$

Namun di India resistensi cultural terhadap pembangunan dan globalisasi telah membangkitkan kelompok Hindu Revivalis yang mendesak India untuk membaikot barang-barang buatan asing. Pendek kata gerakan keagamaan tersebut pada dasarnya adalah gerakan resistensi cultural terhadap pembangunan dan globalisasi. Sebagai gerakan cultural

\footnotetext{
${ }^{9}$ Dr. Nasikin, Op. Cit, h. 204

${ }^{10}$ Dr. Munir Mulkam, Islam Kiri, UGM Press, 2001, h. 35
} 
menentang pembangunan terlokalisir serta tidak mampu mengidentifikasi problem diluar batas desa atau wilayah mereka. Gerakan NGO sering kali membantu gerakan resistensi cultural untuk memperluas gerakan. Gerakan masyarakat adat Yamdena dan Key Besar yang menentang pembabatan hutanh disambut oleh SKEPHI, suatu NGO untuk tingkat Nasional dan akhirnya melibatkan organisasi tingkat Internasional. ${ }^{11}$

Kedua, tantangan dari new sosial movement dan global civil society terhadap globalisasi. Seperti gerakan hijau, feminism, gerakan masyarakat akar rumput. Pada tahun 1992 gerakan untuk menyelamatkan Narmada ini berhasil mendesak bank dunia untyk mencabut dukungan pada proyek DAN di India. Gerakan yang mewarisi sikap kritis Mahatma Ghandi adalah gerakan sosial yang menentang meningkatnya sentralisasi dan watak otoritarian kekuasaan Negara. Gerakan "koalisi anti hutang" di Indonesia, serta berbagai koalisi NGOs menentang WTO adalah fenomena resistensi sosial terhadap globalisasi. Gerakan "Pembaharuan Agraria" yang dilakukan oleh Serikat Buruh di Sumatera Utara dan Konsorsium Pembaharuan Agraria. Serta gerakan petani ramah lingkungan dan perjuangan hak-hak petani serta gerakan revolusi hijau petani Jawa. Pada dasarnya adalah respon gerakan sosial untuk resistensi terhadap globalisasi dan ekspansi.

\section{E. KESIMPULAN}

1. Pembangunan sebagai suatu paradigma dan teori perubahan sosial dewasa ini berada pada masa krisis dan mengalami kegagalan penerapan diberbagai Negara dunia ketiga. Kegagalan pembangunan didunia ketiga justru terjadi pada Negara-negara yang dianggap paling sukses dan paling banyak dijadikan contoh bagi Negara-negara penganut pembangunan lainnya. Yakni Negara-negara kapitalis model NIC (newly Industrialist countries) seperti Korea Selatan dan Taiwan. Kegagalan pembangunan juga terjadi dinegara yang dijadikan model yakni Negara-negara NIC baru seperti Thailand, Malaysia, dan Indonesia.

Sampai saat ini penjelasan berbagai krisis belum selesai. Ada penjelasan yang menyalahkan factor korupsi rezim Negara-negara tersebut sebagai argument untuk menjelaskan kejatuhan capitalisme di Asia yang terjadi secara cepat. Meskipun demikian, suatu diskursus sebelum kejatuhan kapitalisme Asia terjadi telah mulai dibangun dengan percobaan untuk memperbaiki atau mereformasi system kapitalisme. Sebagai suatu proses reformasi maka pendekatan, 
ideology, dan struktur diskursus itu tidak jauh beda dengan system, struktur dan ideologi yang dijadikan landasan teori pembangunan. Diskursus itulah yang dikenal globalisasi.

2. Gagasan developmentalisme segera menjadi program massif, justru setelah menjadi doktrin politik bantuan luar Negeri Amerika baik pada pemerintah dunia ketiga maupun LSM, juga serempak hamoir di setiap Universitas di Barat membuka suatu kajian baru yang dikenal dengan Development studies. Melalui development studies ini, proses penyebar luasan gagasan kapitalisme dipenjuru dunia dipercepat, yakni melalui tehnokrat, intelektual, dan bahkan aktivis LSM dari dunia ketiga yang menjadi pasar utama program studi tersebut.

Para ahli ilmu sosial memainkan peran yang besar dalam menglobalisasikan ideology baru ini, dengan mengajukan gagasan kepada pemerintah Amerika untuk menggunakan berbagai cara dalam rangka mendeseminasikan ideology development dan modernisasi tersebut dengan target khusus dunia ketiga. Pertama, sasaran mereka, untuk menggunakan pengaruh Amerika, kebijakan ekonomi dan perencanaan. Mereka tahu bahwa bantuan Amerika selama ini efektif dalam mempengaruhi kebijakan ekonomi dan perencanaan. Kedua, untuk mendidik pemimpin dunia ketiga baik dalam bentuk training, maupun perjalanan observasi ke Amerika. Saran ketiga, dengan menggunakan saran agama. Banyak studi agama diarahkan pada peran agama dalam development, sehingga perlunya, "sekularisasi" menjadi bahasa resmi pemimpin dunia ketiga. Sedangkan yang terakhir adalah untuk menggunakan fungsi training dan riset dari tenaga Universitas Amerika yang bekerja diluar negeri atas biaya USAID.

3. Globalisasi telah merubah sosial ekonomi suatu masyarkat dengan kemajuan dan keberhasilannya berakibat semakin tertindasnya masyarakat adapt dan masyarakat marjinal kota serta masyarakat marjinal lainnya.

4. Ada dua kelompok gerakan masyarakat yang menentang system globalisasi yangh dicanangkan Barat yaitu gerakan keagamaan dan gerakan budaya.

\section{DAFTAR PUSTAKA}

Bambang Sumitro, Kuliah sosiologi pembangunan, PPs IAIN Raden Intan

Mulkam Munir, Islam Kiri, UGM, 2001. 
Millikan and Pye, 1968, p; 165 dikutip oleh Dr. Mansour Fakih, Runtuhnya Teori pembangunan, pustaka pelajar, Yogyakarta.

Nurdin Fuzie, Transformasi sosial keagamaan dalam perspektif sosiologi, makalh dalam seminar Internasional, 2001

Zaini, teori-teori pembangunan, makalah, 2003.

Fakih Mansour, Runtuhnya Teori Pembangunan, Pustaka pelajar, Yogyakarta, 2001.

Zaeni A, Teori weber dan islam, sosiologi Agama, PPs IAIN Raden Intan 